\title{
Evolution of the Brazilian Publishing Market
}

\author{
Gerson Ramos
}

Published online: 13 April 2013

(C) The Author(s) 2013. This article is published with open access at Springerlink.com

\begin{abstract}
The Brazilian economy grows day by day, but when and how the country will reach its potential as a reader market, is still is a challenge for companies established in the country and for those which wish to plant its flags there. Looking at its recent past and the current transformations, it is possible to imagine that this time for success is pretty closer.
\end{abstract}

Keywords Brazilian book market · Brazilian publishers · Cultura · Brasil · Editora · E-publishing $\cdot$ Digital books $\cdot$ E-readers $\cdot$ Livraria $\cdot$ Livro digital $\cdot$ Saraiva $\cdot$ Submarino

\section{Introduction}

It is surprising that the Brazilian publishing industry market, which is currently rising and gaining more and more strength day-by-day, can be able to make so little information available for those wishing to know it and understand it better.

Although there is a good selection of works that address individually the history of one or other publisher or bookstore by itself, in order to understand the dynamics of this market it is necessary to learn how to the overall sectors move and propel with its background data. Even companies that have already negotiated rights with Brazilian publishers or those who export their printed book to Brazil, still have difficulty understanding how this new economic scenario functions-which is the 7 th greatest economy in the world - and where we might now find almost as many bookstores as we may find publishers.

Much has been said about the fact that over the past 20 years, more than 29 million Brazilians have risen above the line of poverty, and that this represents a large number of new consumers equivalent to the entire population of Peru.

G. Ramos ( $₫)$

Mendonça Furtado, 158-Granja VianaCotia, São Paulo 06706-135, Brazil

e-mail: gerson@vivodelivro.com.br 
However, when these new consumers will begin to turn into book readers is the challenge faced by both the book publishers and bookseller, as well as by the government which has made several investments in the assembly of library collections and programs to encourage reading thereby strengthening the market.

The lack of a formalization regarding the relationships in the book publishing industry added value chain is one of the most challenging points in Brazil's scenario. Between 2003 and 2004, the economists Fábio de Sá Earp and George Kornis, both are faculty of the Federal University of Rio de Janeiro (UFRJ), have performed a broad research and survey which resulted in the book "A Economia $d a$ Cadeia Produtiva do Livro" [The Economics of Book Production Chain], released in 2005. A metaphor presented by the authors was able to precisely illustrate the situation experienced at that moment and, sadly, until nowadays "Brazilian publishing market is like a Mercedes circulating on bare steel rim wheels." This catchphrase demonstrates that, behind the sophisticated showcases of the most beautiful bookstores established in this country, mainly in urban centers and behind published works produced extremely well by Brazilian publishers, we can find, hidden in the closet, an infrastructure that does not match the real aspirations of these companies.

\section{Challenges in the Distribution and Retail Sales Channels}

Excessive informality, conflicts concerning the definition of operating areas between publishers and distributors, very low investment in technology and logistics, and distributors that use absolute no level of automation on their processes of distributing books, are some of the factors which contributed (and still do) to the fact that major problems exist. For example, most sales points and stores are poorly or not even attended by sales staff because selling has become too expensive for most of them, in such a country which has a territory of 8.5 million $\mathrm{km}^{2}$. All of this leads to a concentration of sales in that more than $60 \%$ is generated only in the Southeast region, where the cities of São Paulo and Rio de Janeiro are located.

The National Association of Libraries (ANL) reported in its survey of 2011, that there are a little more than 3,400 bookstores across the country. These stores were in only 676 cities, among more than 5,500 municipalities that exist in Brazil. The twenty largest cities of Brazil have the concentration of more than 1,500 of these bookshops, or $45 \%$ of the sales points (Fig. 1).

A program of the National Library Foundation, linked to the Ministry of Culture of Brazil, put into practice in 2012, has started an unprecedented process of updating collections of public libraries, so that they would acquire their books at the stores closest to their addresses. Following this practice, the distribution of investments rebalanced the scales in favor of the states from the north and northeast of Brazil, the poorest regions of the country. Thanks to a variety of other social policies which have been developed, it has shown the highest rates of GDP growth, with significant improvements in educational, social and, therefore, cultural values.

The average list price of the book in Brazil is the major obstacle to the expansion of the market itself. Except for the books devoted to education, all other segments 


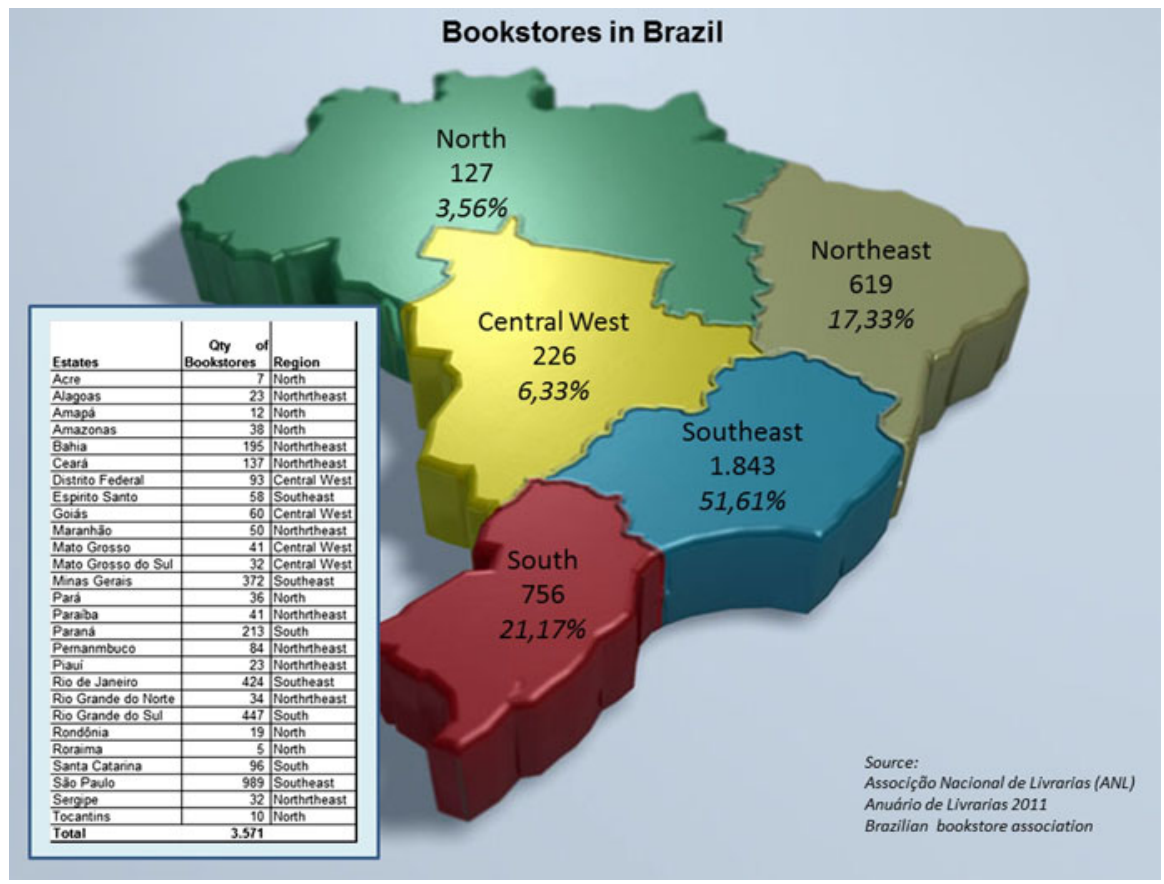

Fig. 1 Concentration of bookstores in a single region is an obstacle to expanding sales

are sold on consignment, which forces publishers to fund and finance the entire book distribution and retail sales chain in Brazil.

But the main reason for the book to be so expensive is that the cover list price is calculated in order to compensate for the inefficiency of the whole operation in the market itself, including all related inefficiencies.

\section{Market Research Information}

Market information will be supplied as soon as marketing research and surveys begin to developed, although up to the moment they are nonexistent. GfK is preparing to launch an effort, but the market awaits Nielsen Brazil, which in 2013 is bringing the tradition of BookScan services to our country.

Those services and surveys will allow for a deeper insight into the functions and behavior of market transformations including identifying trends of this new emerging market on a national scale.

PublishNews, an informative website, which reports on the market, publishes a weekly list of best-selling books. It is easy to see that publishers frequently on this list are not there just because of the interest in specific titles that the books arouse in their readers, but because these companies best deal with the structural distribution and sales issues reported. These companies are often protagonists to cause most remarkable events in the history recorded here since 1995. 
The following is a brief history of the major issues and developments that have occurred over the past 18 years.

1995

- Booknet, the first online bookstore in Brazil opens in Rio de Janeiro.

- Bookstore chain Livraria Nobel invests in franchising and expands to 10 stores, from the initial 4.

- Bookstore chain Livraria Cultura launches its website.

- Beginning of megastore openings. Saraiva opens two stores in São Paulo with over $1,000 \mathrm{~m}^{2}$ each.

- The Dutch group Elsevier arrives in Brazil, acquiring publisher Campus, specialist in Computing and Business titles. The new publisher is called Campus Elsevier.

- Publisher Record begins to aggressively acquire other publishers like Bertrand, Difel, and Civilização Brasileira, that belonged to Altair Brasil.

- Ática Cultural Shopping is opened. It is the biggest bookstore in Brazil, with $4,600 \mathrm{~m}^{2}$. It was financed by the Fernandes Dias family, based on the investments of their publishers Ática and Scipione, the first and the fourth biggest publishers of the country, respectively.

- Publisher Saraiva, specialized in Law and Textbooks, acquires publisher Atual, increasing their market share in textbooks.

- Only a year after its inauguration and with serious administrative problems, Ática Shopping is sold to the French group PPR, owners of the Fnac chain, who began their expansion throughout Latin America.

- Geraldo Pereira and his sons, Marcus and Tomáz, heirs of renowned publisher José Olympio, create commercial trade publisher Sextante.

- Saraiva opens an online bookstore.

1999

- The French group Vivendi, then owners of Hachette and PPR's biggest competitor, together with Publisher Abril, buys Ática and Scipione, becoming the first group with international capital in the Brazilian textbook market.

- Publisher Rocco, already among the 20 biggest publishers, buys the rights for the Harry Potter series and jumps into the top five biggest publishing groups in Brazil. 
- Thanks to substantial foreign investment, Submarino online store is launched with a strong marketing campaign, acquiring Booknet and transferring their headquarters to São Paulo.

- During the expansion of the Internet bubble, many publishing projects are launched, among them, Nobel puts together investors and starts 4 projects:

- B2C portal "Canal Compras"

- E-commerce services "Todo Conteúdo"

- First commercial ebook project "I-Editora"

- B2B portal for Books, CDs, DVDs and Games "Superpedido"

- Saraiva acquires publisher Renascer.

- Livraria Cultura opens its second bookstore, in São Paulo, and start the process of becoming a chain store.

- Pearson Group arrives in Brazil with STM market in view and buys publisher Makron, a very profitable publisher, was an unsuccessful attempt of McGrawHill to enter the Brazilian market and Campus' biggest competitor in Computing and Business sectors.

- Publisher Record buys José Olympio, which then belonged to Xerox. José Olympio was one of the first and most traditional Brazilian publishers, and although it had lost some of its prestige in the previous years, its backlist had many important titles.

- PublishNews sends their first newsletter, then a clipping service about the Brazilian publishing market.

- Publisher Santillana, part of the Spanish giant media conglomerate Prisa, buys Brazilian publisher Moderna, created and directed by author Ricardo Feltre in 1968 and one the three biggest textbook publishers in Brazil.

- Publisher Fundamento: Mauro Halfeld, journalist and economic analyst, launched his publishing house in Curitiba. He will publish many best sellers in children books, among them many licenses from TV and history books for all audiences.

- With the intention putting Brazil on the international literary agenda, Liz Calder, a British literary agent, creates Flip, Festival de Literatura de Parati. The literary festival will grow to become one of the key literary events in the country.

- Ediouro starts acquisitions process to face national and international competitors. The editorial group buys publishers Agir, owner of the eternal bestseller The Little Prince. 
- Campus/Elsevier buys publisher Negócios, a strategy for expansion in the business books segment.

- Unhappy about their representation in the Brazilian Book Chamber (CBL) and the National Publishers' Union (SNEL), a number of small publishers create LIBRE, the Brazilian Independent Publishers League, to confront the market consolidation.

- Global, a specialist in Sociology and History books, changes its profile and begins to invest in the textbook market buying the rights of many famous authors, such as Gilberto Freyre and Marcos Rey.

- Publisher Vida, one of the biggest in the religious sector, launches Rick Warren's The Purpose-Driven Life. It is the first time non-religious bookshops sell a Christian title.

- Saraiva buys publisher Formato and increases their market share in children's books. French publisher Larousse arrives in Brazil, with a start-up created from scratch, no acquisitions.

- Spanish publisher Planeta, after an unsuccessful attempt to buy publisher Record in negotiations that lasted almost a year, arrives in Brazil, hiring staff and acquiring authors from many Brazilians publishers, inflating market prices.

- With a modest market share and a catalog of mainly of self-help books, publisher Sextante buys the rights to a fiction title by an unknown writer and launches The Da Vinci Code in Brazil.

- Created by Jorge Oakim, a novice in the publishing market, Intrínseca gains high visibility with the controversial book Hell by French writer Lolita Pille.

- Alana group buys all the shares of B2B book portal Superpedido and begins a process of transformation of the company into a distributor.

- Positivo group buys the rights to print Aurélio Dictionary that had belonged to Publisher Nova Fronteira since 1985.

- Brasilivros, leading distributor since the 70s, after 2 years facing big financial difficulties, has sought bankruptcy by its creditors.

- Bookstore chain Siciliano, facing financial complications, begins a franchising project and opens their first bookshop in the state of Rio Grande do Sul.

- Alana group buys the shares of Nobel in Fase Logística and changes its operations, creating Biblion Logis, a company specialized in distribution to the publishing market.

- Tecmedd, publisher and distributor, launches Novo Conceito for trade books, trying to diversify its lines up to then dedicated to STM.

- Record buys publisher Best-Seller, which partly belonged to Nova Cultural group. Nova Cultural was the result of the family division of publisher Abril between the Civita brothers. 
- Brazil's President Lula da Silva approves a law that eliminates some taxes on books, trying to reduce prices and help the national distribution.

- Ediouro group acquires Relume Dumará

- Edições SM, another Spanish group, with a strong market share in the children's and textbook segments, create its base in Brazil with focus on education.

- Superpedido begins its operation distributing books with the biggest investment by a company in this sector.

- McGraw Hill, American giant in STM segment, once again opens a Brazilian division to publish book.

- The most comprehensive study about Brazilian publishing market is launched. Conducted by the economists Fábio de Sá Earp and George Kornis, the book "A Economia da Cadeia Produtiva do Livro" presents new information about structural issues in the Brazilian book market.

- Record establishes a partnership with Canadian Harlequin to publish pocket books that would be sold in drugstores and newsstands.

- Santillana group buys $65 \%$ of Objetiva and begins to publish fiction books in Brazil. Planeta buys the rights of Paulo Coelho's books for an official figure of US\$800,000.

- LCL, the largest Brazilian book wholesaler, suddenly is indicted, by involvement in the bankruptcy of Distribuidora Brasilivros, leaving large debts with the publishers and disrupting the whole distribution service in Brazil.

- Acaiaca, a regional distributor from Minas Gerais open an office and a warehouse in São Paulo, to become a national wholesaler.

- After the death of founder Waldir Martins Fontes in 2000, publisher and bookstore Martins Fontes are divided between the two heirs, Evandro and Alexandre.

- With the fusion of Submarino and ecommerce retailer Americanas.com, a new B2W Company is founded.

- Ediouro group and American Christian publisher Thomas Nelson create a joint venture to bring their most successful titles to Brazil; other publishers had already launched some of them.

- Early in the year, two small distributors (VSG and RDS), closed the doors, leaving huge debit again with the publishers, this time mostly with the publishers specialized in Law books.

- Almost 70 years old, publisher Atlas, one of the biggest in the area of Law books, restructures their board, generating speculation about their future. 
- Spanish group Anaya, controller of Larousse, exchanges stocks with Brazilian publisher Escala, and ends up with $51 \%$ of the recently created publishing house.

- Guanabara, the biggest Medical publisher in Brazil, creates Grupo GEN and begins a process of acquisitions, buying Forense (Law) and Método (who publishes textbooks for public exams).

- Ediouro buys $50 \%$ of Nova Fronteira, created by late politician Carlos Lacerda. It was the biggest competitor of publisher Record up to the beginning of the $90 \mathrm{~s}$, when it began to lose market share.

- Ediouro buys Nova Aguillar, also from the Lacerda family, publisher of many luxury books from the biggest names in literature.

- Sextante buys $50 \%$ of Intrínseca, a company that had been gaining market share with a catalog of best sellers.

- In one of the biggest investments in a marketing campaign for a single book, Ediouro launches The Secret. The title remained a long-term bestseller.

- Editor Abril hires J.P. Morgan to evaluate proposals to sell Ática and Scipione.

- Grupo GEN acquires publisher Santos, specialized in the Health segment.

- In one of the longest and most publicized negotiations in the publishing market, Saraiva group announced the acquisition of Siciliano, a group formed by bookstores and publishing house (Arx, Caramelo and Futura). Saraiva becomes then the biggest book retailer in the country.

- Ediouro acquires publisher Desiderata.

- Intrínseca publishes one of the biggest best sellers in the world, Twilight

- Publisher Rocco, from Rio de Janeiro, opens Prumo, a new publishing house in São Paulo with an independent editorial structure with a focus on teen audience.

- For the first time a publishing house cuts the prices of its backlist. Christian publisher Mundo Cristão tries to reposition its titles, especially in the nonreligious market.

- Ediouro creates a digital branch, called Singular, in an attempt to become the main supplier of print-on-demand services, digital books and self-publishing.

- Superpedido, already a leader in distribution of trade books, acquires Distribuidora Tecmedd, becoming the biggest distributor of general books and STM publications.

- Retailer Livraria Cultura gets investment from private equity investment fund Neo, partner of Itaú bank.

- Publisher Companhia das Letras begins a partnership with the American branch of Penguin.

- Publisher Artmed, one of the biggest STM publishers in Brazil, creates Grupo A and acquires the Brazilian division of the American publisher McGraw-Hill that, 
as a consequence of 2008 financial crisis, decides to end their operations in Brazil.

- Portuguese group Leya opens a branch in Brazil after giving up on the acquisition of publisher Nova Fronteira. They were already operating in Mozambique and Angola.

- The first online bookstore dedicated exclusively to digital books opens. Duda Ernany and Ricardo Schermann, newcomers to the publishing market, create Gato Sabido in Rio de Janeiro.

- After it failed to sell their participation in Nova Fronteira, Ediouro acquires all of the publisher and incorporates its operational and commercial areas.

- American group Thomson Reuters acquires publisher Revista dos Tribunais, specialized in Law books.

- Record acquires self-help publisher Verus.

- The First Congress of the Digital Book is organized by a partnership between Brazilian Book Chamber CBL and Frankfurt Book Fair, with a focus on new publishing business technologies.

- Digital Book Distributor, called DLD, is created by a joint venture among publishers Rocco, Objetiva, Sextante and Record, to protect their digital rights against the aggressive prices of online stores and possible foreign competitors entering Brazil. Bookstore Vértice (the former owners of Revista dos Tribunais) acquire distributor Empório dos Livros.

- A division of Gato Sabido, Xeriph is created, to establish a platform of digital distribution for publishing houses that don't want or can't invest on their own in the increasing digital market.

- Submarino takes Gato Sabido onto its online bookselling platform, creating conflicts with other publishers that were already selling through the specialized bookstore. Escala buys back $100 \%$ of its stock from their international partner Anaya.

- Grupo Gen acquires law and academic publisher Forense Universitária.

- Globo publishes Ágape, from Priest Marcelo Rossi. The title will become an alltime best seller, reaching 8 million copies sold in 2 years after its release.

- Leya acquires publisher Casa da Palavra from Rio de Janeiro.

- Saraiva launches a platform to sell digital books with an app called Saraiva Digital Reader.

- Grupo A opens a branch in Portugal, and becomes the first STM publisher from Brazil to make the inverse path in the global market, from Latin America to Europe. 
- Focusing on digital content for college students, Saraiva, Grupo GEN, Grupo A and Atlas create Minha Biblioteca (My Library), a platform for development of digital textbooks from these publishers in different formats.

- Singular, owned by Ediouro, begins a partnership with American book distributor Ingram-Lightning Source, to print digital content through POD in Brazilian territory.

- Using the experience of its shareholders, who came from companies like Disal, specializing distributor in ELT books; Prol, a leading graphic Brazilian printer and Digital Pages, specializing in digital content distribution, a new company called i-Supply is founded, to provide distribution and fulfillment services for $\mathrm{B} 2 \mathrm{~B}$ and $\mathrm{B} 2 \mathrm{C}$ e-commerces.

- Penguin acquires $45 \%$ of Companhia das Letras, becoming the first from the socalled US Big Six to establish operations in the Brazilian trade books market.

- Submarino ends contract with Gato Sabido and makes a deal with the Brazilian division of American group The Copia to operate their digital store.

- Amazon hires an executive from Livraria Cultura Digital to prepare its arrival in the Brazilian market.

- Grupo Gen acquires publisher Roca, another publisher specialized in Medical and Health titles, and publisher A.C. Farmarcêutica, specialized in medical journals.

- Portuguese group Babel creates a publisher in Brazil. The goal is to publish Portuguese language authors.

- In another multi-million dollar negotiation, Paulo Coelho changes publishers again, taking his books to Sextante.

- Fundação Biblioteca Nacional starts a new program of book acquisitions for libraries, involving the entire production chain. Little bookstores sells books to libraries for the first time.

- Livraria Cultura creates the Geek store, a new concept in bookstores, with "geek" products, like comics and action figures.

- Empório dos Livros/Vértice acquires online bookstore Cia dos Livros and tries to become a logistics operator, leading book distribution and book sales to the government.

- Publisher Rideel and Martins Fontes become part of Biblioteca Virtual Universitária, an online library for universities, together with Companhia das Letras.

- In an auction contested by Companhia das Letras and Record, Intrínseca wins the rights to publish Fifty Shades of Grey, with an offer of US\$ 450,000.

- German group Bertelsmann opens an office in São Paulo to advise on investments for the company in Brazil.

- Publisher Novo Conceito joins with digital distributor DLD.

- Brazilian market is shaken with information published by Bloomberg that Amazon was negotiating for the acquisition of Saraiva chain, which turned out 
not to be true. Saraiva shares become inflated, while Submarino's shares dropped on that day.

- Record acquires Paz e Terra.

- Kobo, a Canadian company in the digital book market, hires a professional from Gato Sabiudo to become its Country Manager and starts its strategy to enter the Brazilian e-book market.

- Livraria Cultura announces a partnership with Kobo and launched in the early December its digital book store, also selling the Kobo device readers in its own physical stores.

- On the same night of the launch of the Livraria Cultura/Kobo store, the start of operations with a difference of a few minutes, the Brazilian digital books stores from Google and Amazon, in this order. This night, started the internationalization of the e-book market in Brazil.

- A few days before Christmas, Livraria da Vila announces partnership with Amazon to sell in its stores the Kindle e-book reader device.

- Brazil's President Dilma Rousseff signs a document to create "Vale Cultura", which will benefit 12 milion Brazilian workers with $\mathrm{R} \$ 50,00$ monthly to purchase goods and cultural services.

$2013 \ldots$

With a quarter of the year already elapsed, everything indicates that fusions, mergers and acquisitions should still continue to occur. The windows of opportunity are just opening up, especially for the companies that devote attention to the changing publishing processes and good business management. Publishers need also to be aware that the current number of readers in the country are only the visible part of a market that has a lot to be still explored. Growth will develop not only in publishers advancing in the digital world, but also in retail expansion in regions that are only now beginning to read and also in providing services, from logistics to distribution.

In late 2012, a bill endorsed by President Dilma has created the Culture Voucher, which will benefit more than 12 million Brazilian workers who will receive $\mathrm{R} \$$ 50,00 per month to purchase cultural goods or services, which directly affects the book market. This government legislation is expected to come into force in the second half of 2013, this action could mark a major and positive transformation of the country. Monteiro Lobato, the most famous Brazilian author of books for children, and himself an entrepreneur in the publishing market in the first half of the twentieth century, said that a country is made from Men and Books.

So, the time has come for Brazil.

Open Access This article is distributed under the terms of the Creative Commons Attribution License which permits any use, distribution, and reproduction in any medium, provided the original author(s) and the source are credited. 